\title{
Measures of Inflation in India
}

\author{
Deepika Goel \\ Associate Professor, Aryabhatta College, University of Delhi, New Delhi - 110021, India \\ deepika_goel@hotmail.com
}

\begin{abstract}
This paper brings out the salient features of different measures of inflation in India. Before adopting the flexible inflation targeting framework, RBI focused on using Wholesale Price Index (WPI) as the measure of headline inflation. Consumer Price Index for Industrial Workers (CPI-IW) was the widely used measure of CPI inflation. International practice however, suggests the use of CPI as the measure of headline inflation. There are also limitations of using WPI as a measure of inflation. Hence, Central Statistics Office (CSO), launched a new measure of CPI, known as CPI-Combined which incorporates all Indian rural and urban households. Stylized facts used in the paper show that inflation dynamics in India is characterised by a divergence between CPI-IW and WPI indices. Against this backdrop, the paper examines Granger Causality between the two indices in a Vector Auto Regressive framework. Results of the study indicate that there is bidirectional causality between the two indices which does not get affected even during the period of global financial crisis, when the divergence between the two indices was observed for the longest duration.
\end{abstract}

Keywords: CPI Inflation, Granger Causality, Impulse Response Function, Inflation, WPI Inflation, FEVD, VECM

JEL classification: E31, E58, E62, C32, F62

\section{Introduction}

Price stability is one of the key objectives of every macroeconomic policy formulation in an economy as it helps stabilize nominal interest rates, thereby promoting higher investment and growth. High levels of inflation, or price instability, may reduce purchasing power in future and therefore may adversely affect savings, investment and economic growth. Inflation may also increase the chances of higher business risk and lower export competitiveness.

In India, inflation is measured using various price indices. The most commonly cited indices are Wholesale Price Index (WPI) which is a measure of average change in wholesale prices of goods in the economy and Consumer Price Index (CPI) which measures the change in the general level of retail prices of selected goods and services that households purchase for the purpose of consumption.
Other available indices include the GDP deflator which is a complete measure of inflation defined as a ratio of GDP at current prices to GDP at constant prices and Private Final Consumption Expenditure (PFCE) deflator which provides an implicit inflation estimate for the economy. Both the indices are derived from National Accounts Statistics. However, both GDP deflator and PFCE deflator are available only on a quarterly basis with a lag of two months since 1996. For this reason, the focus of this study is on WPI and CPI for industrial worker (CPI-IW) indices and the issues that surround Indian inflation measured using these two indices.

CPI in India is compiled for four different segments of the population that is Industrial Worker (IW), Agricultural Labour (AL), Rural Labour (RL) and urban non-manual employees (UNME) . Central Statistics Office (CSO), started releasing data on a new measure of 
Consumer Price Index (CPI) with base $2010=100$ for all India as well as States and Union Territories since January 2011. This new index of CPI is known as Combined CPI and includes price indices separately for rural and urban population. New CPI comprises of computational changes which makes it more robust as compared to the old CPI index. This index is constructed to ensure better comparability with CPI of other countries.

Until recently, WPI was considered as the measure of headline $e^{c}$ inflation because it was available at a higher frequency. Since, WPI also covered large number of items at a disaggregated level, it was favoured as an index for a better analysis of inflation in the economy.

Mohanty ${ }^{24}$, Subbarao ${ }^{\frac{36}{4}}$, Patnaik, Shah and Veronese $e^{27}$ among others argue that WPI does not cover price of services. They also argue that although WPI is considered as measure headline inflation, it does not reflect the consumer price situation in the economy.

Mohanty ${ }^{24}$ highlights that while each measure of inflation has its strengths and weaknesses, the measure of inflation which is selected as a policy variable, should be able to capture the interaction of effective demand and supply in the economy at frequent intervals. He asserts that the trend in various measures of inflation during the recent years has raised several conceptual measurement issues. Firstly, divergence between WPI and CPI-IW inflation during various time periods, especially after early 2008 , has raised questions on the suitability of a particular measure selected as headline inflation by the Central Bank. Secondly, the representativeness of WPI has reduced over time, as it does not capture the price movement in the services sector which, is an increasing share of GDP- about 53.77 percent at 2011-12 prices in 2016-17.

This paper focuses on the issue of divergence between WPI and CPI-IW inflation in the recent years by using the Granger causality test in a Vector Auto Regressive (VAR) framework. Through this approach, bi-directional relationship between WPI and CPI-IW inflation is analysed. The paper is further organised as follows. Section 2 provides the architecture of inflation measured by WPI, CPI-IW and CPI-Combined (Rural+Urban) indices. Section 3 analyses the trend in inflation as measured by these three indices. Section 4 provides a brief survey of the literature. Section 5 explains the data sources and the methodological framework. Section 6 discusses the estimation results and a conclusion is provided in Section 7.

\section{Measures of Indian Inflation}

As discussed above Indian inflation is measured by various indices- WPI available for the economy as a whole, segment specific CPI, namely, CPI-IW, CPI-AL, CPI-RL and CPI-UNME and a national level CPI-Combined (Rural+Urban) which was released in 2011. The inflation target set by the central bank for monetary policy is now given in terms of an all-India CPI-Combined (CPI-C) index. In order to understand the behaviour of inflation in India and analyse the recent divergent behaviour of WPI and CPI-IW indices, we first discuss the architecture of the various price indices available in India.

\subsection{Wholesale Price Index (WPI)}

WPI series is compiled and released by the Office of the Economic Adviser (OEA), Department of Industrial Policy and Promotion (DIPP), Ministry of Commerce and Industry, Government of India (GOI). WPI tries to capture the movement of prices in the economy at the wholesale level. It is used as a deflator for various nominal macroeconomic variables to derive the real variables. The base year of WPI is revised from time to time in order to sync it up with the other indicators in the economy. WPI with base year 2004-05 was launched in September 2010. Its next revision occurred recently with base year 2011-12 which synchronized it with the base year of other important indicators such as GDP and Index of Industrial Production (IIP). The new series was introduced in May $2017^{\mathrm{d}}$.

As per the manual on WPI $(2004-05=100)$ released by CSO, WPI is based on select items which are considered important regionally on the basis of traded values ${ }^{\mathrm{e}}$ of commodity baskets. Construction of WPI series with base year 2004-05 involves taking each product group in the commodity basket which covers at least 80 percent of the traded value at the group level. The components of WPI are divided into three groups: Primary Articles which mostly consist of Food items; Fuel and Power; and Manufactured Products.

Table 1 summarises the comparative weights, number of items and quotations for different components of old and new WPI series.

According to the WPI manual (base 2011-12=100), GOI ${ }^{13}$, "In the WPI (base 2004-05) series, ex-factory prices, inclusive of excise duties, were used as first 
Table 1. Comparative Weights, No. of Items and No. of Quotations in Old and New WPI Series

\begin{tabular}{|c|c|c|c|c|c|c|}
\hline \multirow[t]{2}{*}{ Major Group / Group } & \multicolumn{2}{|c|}{ Weight } & \multicolumn{2}{|c|}{ No. of Items } & \multicolumn{2}{|c|}{ No. of Quotations } \\
\hline & 2011-12 & 2004-05 & 2011-12 & 2004-05 & 2011-12 & 2004-05 \\
\hline All Commodities & 100 & 100 & 697 & 676 & 8331 & 5482 \\
\hline I Primary Articles & 22.62 & 20.12 & 117 & 102 & 983 & 579 \\
\hline II Fuel \& Power & 13.15 & 14.91 & 16 & 19 & 442 & 72 \\
\hline III Manufactured Products & 64.23 & 64.97 & 564 & 555 & 6906 & 4831 \\
\hline
\end{tabular}

Source: Office of the Economic Adviser, DIPP, Ministry of Commerce and Industry, GOI.

point of bulk sale in respect of manufactured products. However, in the 2011-12 WPI series, the effective prices for Manufactured Products used for compilation has been changed to be defined as the "basic/list price- rebate/ trade discount", thus leaving out any indirect taxes such as Central Excise Duty (CED) as part of price definition."

Excluding indirect taxes from price definition is in concordance with the international practice of computing inflation and brings it closer to the concept of producer price index.

WPI series with base year 2004-05 is calculated in the following manner. Firstly, the price index for each commodity is calculated individually using the price relatives $^{\mathrm{g}}$ for all price quotations of a commodity. Then a simple arithmetic mean is computed for all price relatives. The same procedure is adopted for all 676 price quotations to obtain 676 price indices.

However, the procedure to compute price indices for WPI with base year 2011-12 has changed. First, the elementary price index is calculated using "Jevons Index formula", which uses the Geometric Mean (GM) of price Relatives. This is the lowest level of aggregation which yields the price indices. In the second stage, the elementary price indices are aggregated using weighted Arithmetic Mean (AM) and higher level indices are obtained using Laspeyre's index formula ${ }^{\mathrm{h}}$.

As pointed out in the WPI manual GOI $\frac{13}{}$, WPI data collection is not done on a defined periodicity and there are no pan-India collection centres. Price quotations for manufactured items are collected through online surveys conducted by the Ministry of Commerce and Industry whereby designated factories submit their data online. Price quotations for food items are put together by the Ministry of Agriculture whereas fossil fuel prices are put together by Ministry of Petroleum and Natural Gas and by Public Sector Units (PSUs). Earlier, WPI data was released on a weekly basis by Ministry of Commerce and Industry but since February 2012, it is available only on a monthly basis.

The WPI based inflation is used by the government in formulation of trade, fiscal and other economic policies. Business firms, policy makers, statisticians, and accountants use WPI as a useful objective indexing tool when they formulate price adjustment clauses. However, there are also certain limitations in the use of WPI index. Price of services is not included in WPI index. Moreover, for all economic policymaking, the CPI is used as a relevant indicator, internationally and not the WPI.

\subsection{Consumer Price Index (CPI)}

Consumer prices measure the retail prices of goods consumed by the consumer in the economy. CPI number provides a measure of change in the living costs of workers, so that their wages could be compensated to the changing level of prices. CPI in India is constructed for different segments of the population. There are five different measures of CPI:

- $\mathrm{CPI} /$ Industrial Workers (CPI-IW).

- CPI/Agricultural Labourers (CPI-AL).

- CPI/Rural Labourers (CPI-RL).

- CPI/Urban Non-Manual Employees (CPIUNME).

- CPI-Combined (CPI-C).

The first four measures are segment specific measures of CPI. Out of these, the first three are compiled by the Labour Bureau, Shimla whereas CPI-UNME is compiled by the CSO based at New Delhi. Among these four measures, CPI for Industrial workers (IW) has a broader coverage and is the most commonly used index than the other indices. It is used as a cost of living index in the organised sector of 
the economy. It is currently computed with base year 2001 . Labour Bureau has recently recommended that the base year of CPI-IW be changed to 2013-14. The other three indices are not so commonly used because of the older base year used in compiling them ${ }^{\mathrm{i}}$, as the older base fails to capture the structural transformation of the economy. The fifth measure of CPI, CPI-Combined, is being released by CSO since January 2011.

An all-India weighted index for CPI-IW with base $1960=100$ was started for 50 centres on the basis of weighting diagram drawn by conducting the Family Living Survey in 1958-59. Under this series, the coverage of CPI-IW is limited to three sectors; factories, mines and plantations. The coverage of the series with base 1982 and 2001, is extended to four more sectors; Railways, Public Motor Transport Undertakings, Electricity Generation, and Ports and Docks. Under the CPI-IW series with base $2001=100$, labour bureau compiled data for 78 selected centres and for an all-India Index. These centres were selected on the basis of their industrial importance in the country. Different product groups used in compilation of CPI-IW are: Food, Pan, Supari, Tobacco and Intoxicant, Fuel and Light, Housing, Clothing, Bedding and Footwear and Miscellaneous. The retail prices used in the index calculation are those that are charged from consumers for cash transactions and are inclusive of all taxes which are payable by him.

CPI-IW index is compiled and released every month with a time lag of about 4 weeks. The index is compiled using Laspeyre's Formula. The compilation is first done, at the sub-group level and then at group level and lastly at the basket level, which is called the general CPI-IW index.

The National Statistical Commission (NSC) constituted under Dr. C. Rangarajan in 2001, observed in its report that CPI numbers released by the labour bureau cater to specific segments of the population and could only be considered as partial indices. It is also argued that CPI-IW does not reflect changing pattern of demand that has occurred over time. This Commission, therefore, recommended for compilation of CPI for Rural and Urban areas separately. The Central Statistics Office (CSO), Ministry of Statistics and Programme Implementation started releasing three new measures of Consumer Price Indices (CPI) with base $2010=100$ from January 2011. These are:

- CPI-Combined for all-India and States or Union Territories.
- CPI-Rural for Rural areas.

- CPI-Urban for Urban areas.

Earlier, these series were available with base year 2010 but recently in 2016 the base year of these series is revised to 2012 .

The basket of items and their weighting diagrams are constructed using the Modified Mixed Reference Period (MMRP) data of Consumer Expenditure Survey (CES), 2011-12, which is 68th Round of National Sample Survey (NSS). Data on prices are collected from 1181 village markets which cover all districts and 1114 urban markets spread over 310 towns of the country.

The components of CPI-Combined are: Food and Beverages which constitute a weight of 46 percent in the index; Pan, tobacco and Intoxicants; Clothing and Footwear, which constitutes a weight of 6 percent; Housing constitutes of 10 percent weight and Fuel and Light which constitutes a weight of 7 percent. Finally, miscellaneous category comprises of household goods, education, recreation, health services, transport and communication and personal care which constitutes a weight of 28 percent in the index.

Price relatives in the elementary indices of the new CPI series are computed using GM. This is also in line with the international practice of computing CPI. In the CPI-IW series, AM was used for computing relatives. The advantage of using GM is that it helps to even out volatility of the indices as GM is less affected by extreme values.

In the second stage these elementary price indices are aggregated to obtain higher level indices using consumption expenditure as weights. For this purpose, Laspeyeres index formula is used. Table 2 summarises the basic differences in different CPI and WPI indices in India.

The comparison in Figure 1 reveals that food has the largest weight of 46 percent in CPI-IW $(2001=100)$ as compared to WPI $(2004-05=100)$ where the weightage of food products is only 14 percent. The weightage of fuel group is higher in WPI, which is approximately 15 percent as compared to 6 percent in CPI-IW.

Data for new CPI series, CPI-Combined is available only after January 2011 which does not give enough observations to carry out the analysis. Hence, for the present study, we use WPI index with base year 2004$05=100$ and CPI-IW with base year 2001=100. The study 
Table 2. Comparison of Different Prices Indices in India

\begin{tabular}{|c|c|c|c|c|c|c|}
\hline & CPI-Combined & CPI-IW & CPI-AL & CPI-RL & WPI & WPI \\
\hline Base year & 2012 & 2001 & $1986-87$ & $1986-87$ & 2004-05 & 2011-12 \\
\hline Universe & $\begin{array}{l}\text { All India Rural \& } \\
\text { Urban Households }\end{array}$ & $\begin{array}{l}\text { Households } \\
\text { of IW }\end{array}$ & $\begin{array}{l}\text { Households } \\
\text { of AL }\end{array}$ & $\begin{array}{l}\text { Households } \\
\text { of RL }\end{array}$ & $\begin{array}{c}\text { All } \\
\text { transactions at } \\
\text { first point of } \\
\text { bulk sale }\end{array}$ & $\begin{array}{l}\text { Any indirect taxes } \\
\text { such as Central } \\
\text { Excise Duty (CED) } \\
\text { are left out as part } \\
\text { of price definition }\end{array}$ \\
\hline $\begin{array}{l}\text { Centres/ price } \\
\text { quotations }\end{array}$ & $\begin{array}{l}1181 \text { village } \\
\text { and } 1114 \text { urban } \\
\text { markets covering } \\
\text { all districts and } \\
310 \text { centres }\end{array}$ & $\begin{array}{l}\text { Selected } \\
\text { markets in } \\
78 \text { selected } \\
\text { centres }\end{array}$ & \multicolumn{2}{|c|}{$\begin{array}{l}\text { Shops and markets catering to } \\
20 \text { States ( } 600 \text { villages })\end{array}$} & $\begin{array}{c}5482 \\
\text { quotations }\end{array}$ & 8331 quotations \\
\hline Items covered & 299 & 393 & \multicolumn{2}{|c|}{182} & 676 & 697 \\
\hline \multicolumn{7}{|c|}{ Weights of major groups } \\
\hline $\begin{array}{c}\text { Food, } \\
\text { Beverages and } \\
\text { Tobacco }\end{array}$ & 48.24 & 48.47 & 72.94 & 70.47 & 26.07 & 25.29 \\
\hline Fuel \& Light & 6.84 & 6.42 & 8.35 & 7.9 & 14.91 & 13.15 \\
\hline Housing & 10.07 & 15.29 & - & - & 59.02 & \\
\hline $\begin{array}{l}\text { Clothing \& } \\
\text { Footwear }\end{array}$ & 6.53 & 6.58 & 6.98 & 9.76 & & 61.56 \\
\hline Miscellaneous & 28.32 & 23.32 & 11.73 & 11.87 & * & * \\
\hline Total & 100 & 100 & 100 & 100 & 100 & 100 \\
\hline $\begin{array}{l}\text { Basis for } \\
\text { Weighting } \\
\text { Diagram }\end{array}$ & $\begin{array}{l}\text { 68th Round } \\
\text { Consumer } \\
\text { Expenditure } \\
\text { Survey } \\
(2011-12)\end{array}$ & $\begin{array}{l}\text { Working } \\
\text { Class Family } \\
\text { Income and } \\
\text { Expenditure } \\
\text { Survey } \\
(1999-2000)\end{array}$ & $\begin{array}{l}\text { 38th Round } \\
\text { of Consumer } \\
\text { Expenditure } \\
\text { Survey (1983) } \\
\text { - for AL }\end{array}$ & $\begin{array}{l}\text { 38th Round } \\
\text { of Consumer } \\
\text { Expenditure } \\
\text { Survey (1983) } \\
\text { - for RL }\end{array}$ & $\begin{array}{l}\text { Gross Value of } \\
\text { Output (GVO) } \\
\text { at current } \\
\text { prices, NAS } \\
(2007)\end{array}$ & $\begin{array}{l}\text { GVO at current } \\
\text { prices, (NAS) for } \\
\text { the year 2009-10 }\end{array}$ \\
\hline Methodology & $\begin{array}{c}\text { GM for } \\
\text { elementary } \\
\text { item index and } \\
\text { Laspeyres Index } \\
\text { formula for higher } \\
\text { level index }\end{array}$ & \multicolumn{4}{|c|}{ Weighted AM according to Laspeyres Index Formula } & $\begin{array}{l}\text { GM for elementary } \\
\text { item index and } \\
\text { Laspeyres Index } \\
\text { formula for higher } \\
\text { level index }\end{array}$ \\
\hline $\begin{array}{l}\text { Compiling } \\
\text { agency }\end{array}$ & $\mathrm{CSO}, \mathrm{GOI}$ & \multicolumn{3}{|c|}{ Labour Bureau, GOI } & $\begin{array}{c}\text { Ministry of } \\
\text { Commerce \& } \\
\text { Industry, GOI } \\
\end{array}$ & $\begin{array}{c}\text { Ministry of } \\
\text { Commerce \& } \\
\text { Industry, GOI }\end{array}$ \\
\hline
\end{tabular}

Source: Updated and adopted from Gupta and Siddiqui (2014), Office of the Economic Adviser, GOI, Ministry of Commerce and Industry, DIPP for WPI and Labour Bureau, GOI for CPI-IW/AL/RL and CSO, GOI for CPI-Combined. 

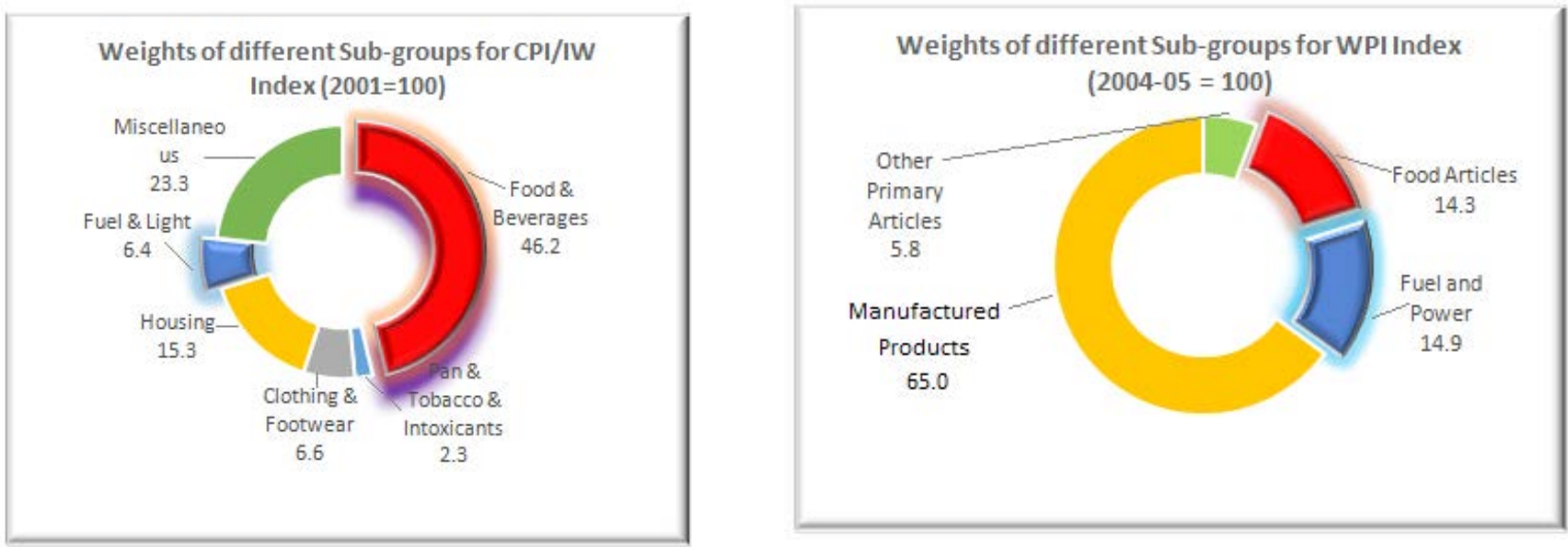

Figure 1. Weights of Different Sub-Groups in WPI and CPI-IW Inflation

is conducted using monthly data for the time period April 1996 to February 2017.

\section{Broad Trends in Indian Inflation}

\subsection{WPI Inflation (2004-05=100)}

The post-reform period after 1991 saw a surge in WPI inflation to double digit figures until 1995-96. This was primarily due to phased opening up of the Indian economy and rise in international fuel prices. By December 1995, inflation declined to almost 6 percent. It remained low for most of the later years due to stable prices of primary articles and food grains. Inflation, again reached a peak of 8.84 percent in September 1998 due to rise in prices of food articles especially vegetables, pulses and edible oils. The year 1999-2000 was again characterized by low inflation and adequate supply of products of daily consumption. Average inflation rate during 2001-02 was 4.7 percent which was the lowest in past 2 decades. There was a record public stock of food grains during this period with Food Corporation of India (FCI), which provided stability to food grain prices. The effect of increase in fuel prices in the previous year's also evened out. Manufactured product inflation recorded a marginal increase due to the impact of global recession, increased international competition, suppressed domestic demand and industrial slowdown. All these factors contributed to a low inflation rate in the country. WPI inflation has been on a decelerating trend since September 2004. It is recorded at 5.2 percent in January 2005 with an average inflation of 6.5 percent in 2004-05. Fiscal and monetary measures together led to the easing of inflationary situation by 2005-06. The situation of high inflation in 2006-07 and 2008-09 was aggravated by demand side factors such as high money supply growth that remained above 20 percent for nearly two years. A rise in international crude oil prices and high international commodity prices led by rise in prices of iron and steel, raw cotton and textiles led to an increase in inflation from 7.7 percent in March 2008 to 12.9 percent in August of the same year.

The year 2008-09 showed a different inflationary trend because of global slowdown and decline in international commodity prices. WPI inflation declined sharply to 0.3 percent on March 2009 (Figure 2). This downward trend can be attributed to low administered prices of petroleum products, which turned negative at (-) $6.1 \%$ and prices of iron and steel which declined to (-) 18.4 percent. During the period 2010-13, rising inflation expectations, hike in vegetable prices as a result of untimely rainfall and rise in international commodity prices led to high inflation. Continuous pressure from increase in wages and protein-food inflation kept WPI inflation high at around 7.5 percent during 2012-13. Inflation during this time reflects a combination of factors such as spill over impact from fiscal imbalances; pass through from exchange rate depreciation and shortfall in supply. WPI inflation measured on year on year basis saw a decline 
of 4.6 percent in May 2013. This however, increased to 6.5 percent in September 2013 owing to an increase in food and fuel prices (Figure 3). Increase in prices of food articles have been primarily due to an increase in prices of vegetables. High input costs, rising wages and inelastic supply were responsible for high food inflation which in turn had an adverse impact on inflation expectations. Figure 3 shows that high inflation in 2013-14 and 201415 is largely driven by continued increase in food and fuel group inflation which together has a weight of about 28 percent in WPI. Decline in WPI inflation was observed in second and third quarters of 2014-15 and it declined to 3.9 percent and 0.5 percent respectively. WPI declined by 0.4 percent in January 2015 as compared to January 2014. As fuel has larger weight in WPI, the decline in fuel prices led to a sharper reduction in WPI (Figure 2). The average WPI inflation declined to (-) 2.6 percent in 2015-16 from 2.0 percent in 2014-15 due to weak global commodity prices especially crude oil and also due to adverse base effect. Owing to increase in global energy prices and prices of metals, WPI inflation averaged at 3.1 percent for the year 2016-17.

\subsection{CPI Inflation: CPI-IW}

CPI inflation peaked at 13.2 percent in 1998. The uptrend was contributed by an increase in prices of food products such as pulses, vegetables, and edible oils. CPI-IW inflation averaged at around 6 percent from 2000-2006 and 9 percent from 2006-2013. After peaking at 12.1 percent year-on-year growth in November 2013, CPI-IW inflation collapsed to 4.3 percent in December 2014. It again accelerated to 5 percent in October 2015. The disinflation over 2016-17, has been accompanied by a fall in the global oil and commodity prices, a sharp fall in global food prices, a new monetary policy regime aimed at anchoring inflation expectations, a new government working on alleviating food supply bottlenecks, and continued restraint on agricultural support prices. Figure 4 shows the drivers of CPI-IW inflation in recent years.

\subsection{CPI Inflation: CPI-Combined}

The new all-India CPI was close to double-digit between 2012 and 2014, averaging 10.1 percent in 2012-13 and 9.8percent in 2013-14. Since then, however, there has been a dramatic plunge. Average inflation fell to 6 percent in 2014-15 - 400 bps $^{\mathrm{k}}$ lower than the previous two years. And in 2015-16, it is another 140 bps lower, averaging 4.6 percent between April and October. The momentum of inflation, measured by the annualized quarterly growth in the seasonally adjusted CPI has also declined from 12.9 percent during the last quarter of 2013 to just 2.9 percent quarter-on-quarter, from August-October 2015. Figure 5 depicts that the divergence between WPI and CPI is also evident in the new indices that is CPI Combined and WPI with base 2011-12. This divergence between the two indices is witnessed recently during January 2015 to mid-2016.

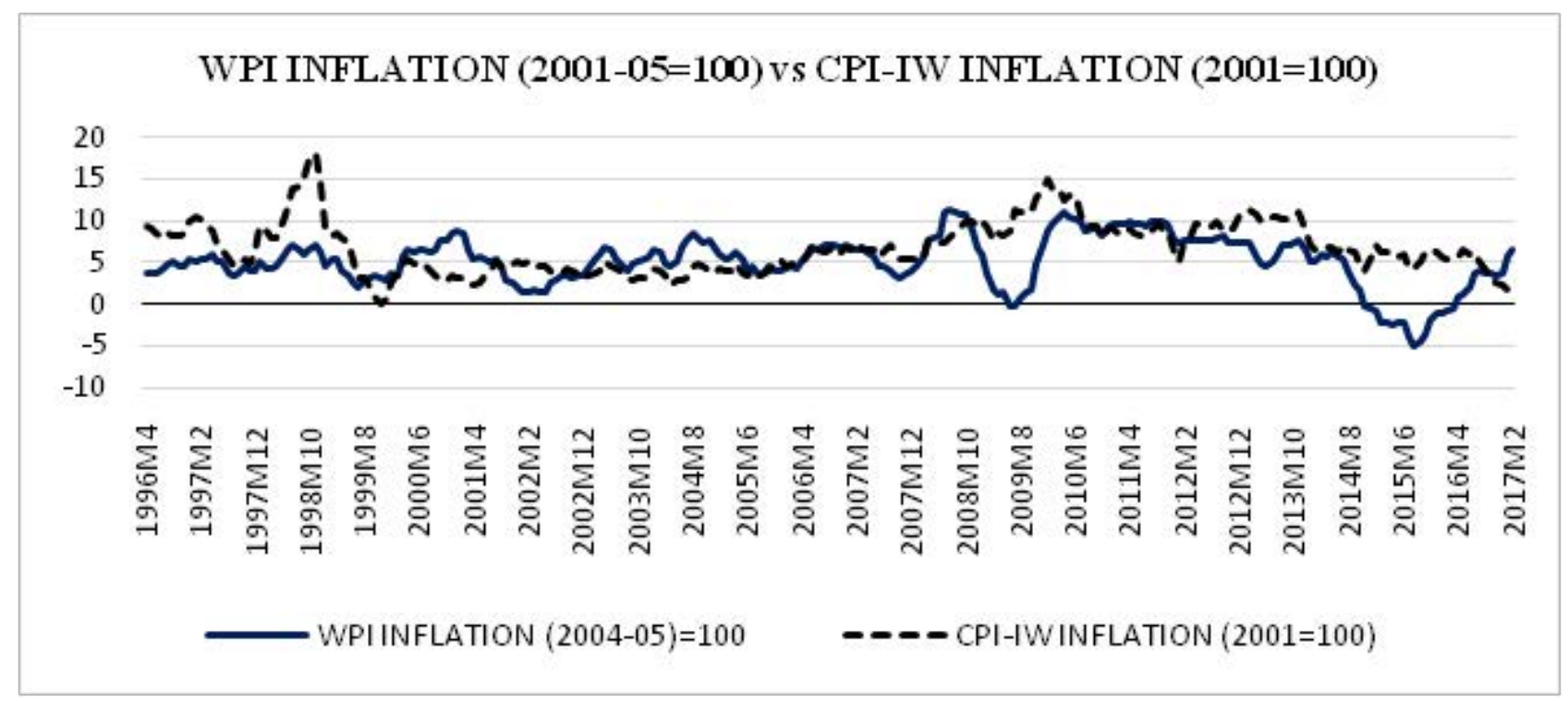

Figure 2. WPI Inflation (2004-05=100) vs CPI-IW Inflation $(2001=100)$ 


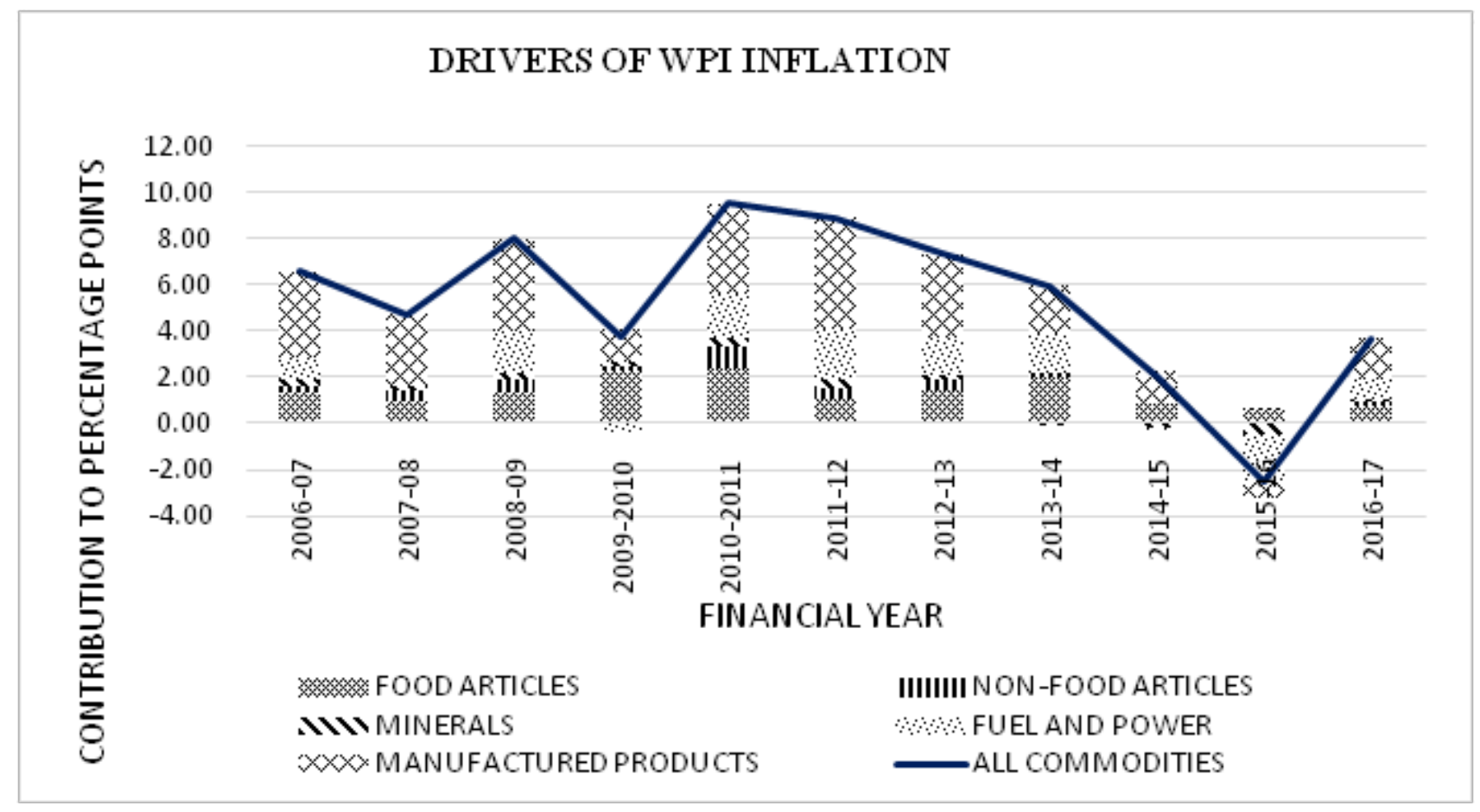

Figure 3. Drivers of WPI Inflation (2004-05=100) based on Financial Year Averages

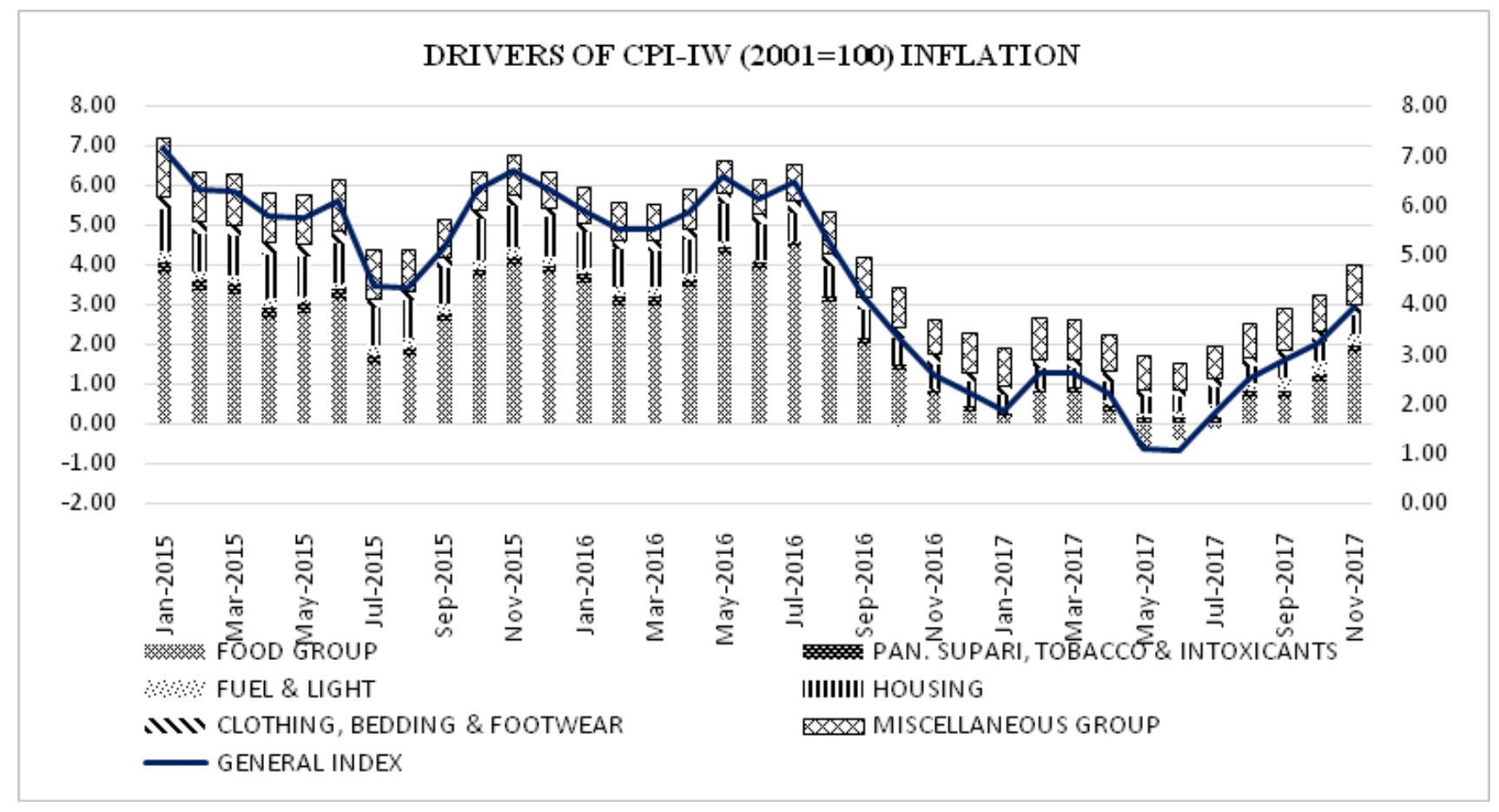

Figure 4. Drivers of CPI-IW $(2001=100)$ Inflation 
CPI Inflation decreases to 8.1 percent in February 2014 from 11.2 percent in November 2013 due to decrease in vegetable prices. Cereals and products posted a significant decrease at 9.9 percent in February 2014 from 12 percent in November 2013. Food and beverages group which has an overall weight of 47.6 percent in CPI combined has contributed significantly to overall CPI inflation during April 2012 to December 2013. Inflation in this segment decreases markedly from 14.7 percent in November 2013 to 8.6 percent in February 2014 due to decrease in vegetables and sugar prices.

Entire process was driven by food prices. CPI inflation excluding food and fuel remained high and persistent at 8 percent in Feb 2014 as compared to 8.1 percent in Jan 2014 (Figure 6). High inflation with respect to CPI services reflected the role of wage pressures and other second round effects.

\subsection{Divergence between CPI and WPI Inflation}

Figure 2 illustrates that WPI and CPI-IW inflation have moved together except during the global financial crisis of 2008. WPI inflation registered a sharp decline while CPI inflation rose sharply during 2009-10. Specifically, CPI increased from 9.1 percent in 2008-09 to 12.2 percent in 2009-10 and in contrast WPI fell from 8percent to 3.8 percent during the same period. The sharp surge in consumer prices was due to adverse global and domestic factors with high food and fuel prices dominating overall CPI. WPI inflation fell below 2 percent in 8 out of 12 months in 2009 as this was broadly due to a fall in industrial production driven by global recession. Wholesale food prices increased by 26 percent while overall wholesale prices dropped by 89 percent in 2009 . This rise in wholesale food prices was not captured by WPI as the weightage for food articles is just 14.3 percent compared to 65 percent for manufactured products in this index. On the other hand, the weightage for food is 57 percent in CPI items which better captures the impact of food prices. Further, wholesale prices do not take into account the substantial margins at the retail level, which tend to rise whenever there are shortages.

In another instance, WPI inflation increased from 5.8 percent in July 2013 to 6.1percent in August 2013. However CPI inflation declined from 9.6 percent to 9.5 percent in the same month. According to D. Subbarao, the former governor of RBI,
"To some extent, the divergence between WPI and CPI can be attributed to statistical differences stemming from coverage, classification of items and the relative weights of their constituents. However, there could be other reasons for this as well. For example, higher transaction costs, taxes, etc. are reflected in the CPI but not in the WPI"

It was observed that food price inflation accounted for much of the gap between the two indices at that moment. WPI food inflation increased from 10.3 percent year-on-year basis to 18.2 percent in August 2013 but CPI food inflation declined from 11.7 to 10.9 percent over the same period.

There are three significant periods (of duration more than a year) of divergences between CPI-IW and WPI inflation rates. In the first period (September 2003 to October 2005) the divergence was on the reverse with CPI-IW averaging 3.7 percent while WPI averaged higher at 5.7 percent. During the second period which started in November 2008 and lasted till March 2010, the divergence reversed with CPI-IW averaging 10.3 percent while WPI averaged at 4.3 percent. Similar divergence is also observed for the new CPI where by CPI-C averaged 436 bps higher than WPI. The gap between CPI-C and WPI based inflation increased to a high of 10 percentage points in September 2015 and disappeared in May 2017 when both CPI-C and WPI based inflation stood at 2.2 percent. On a yearly basis, the gap between the two increased from 4.7 percent in $2014-15$ to 8.6 percent in $2015-16$ and it further narrowed down to 2.8 percent in 2016-17 (Table 3). The convergence achieved in May 2017, can be attributed to stability in prices of commodities which constitute a major part of WPI basket and revision in the base year for Wholesale Price Index from 2004-05 to 2011-12.

According to Mohanty ${ }^{24}$, the major reasons for the divergence that was observed earlier between the two indices are:

- Key driver for divergence has been the food articles, which have a higher weight (45.9 percent) in CPI than in WPI (26.1 percent). Food prices since 2008 are significantly higher resulting in the widening gap between the two indices.

- Commodity prices like metals have a much higher weight in WPI as compared to CPI. Similarly fuel and power category has a weight of 14.9 percent in WPI, compared to CPI, where the weight is 6.8 percent. In the last two periods of 


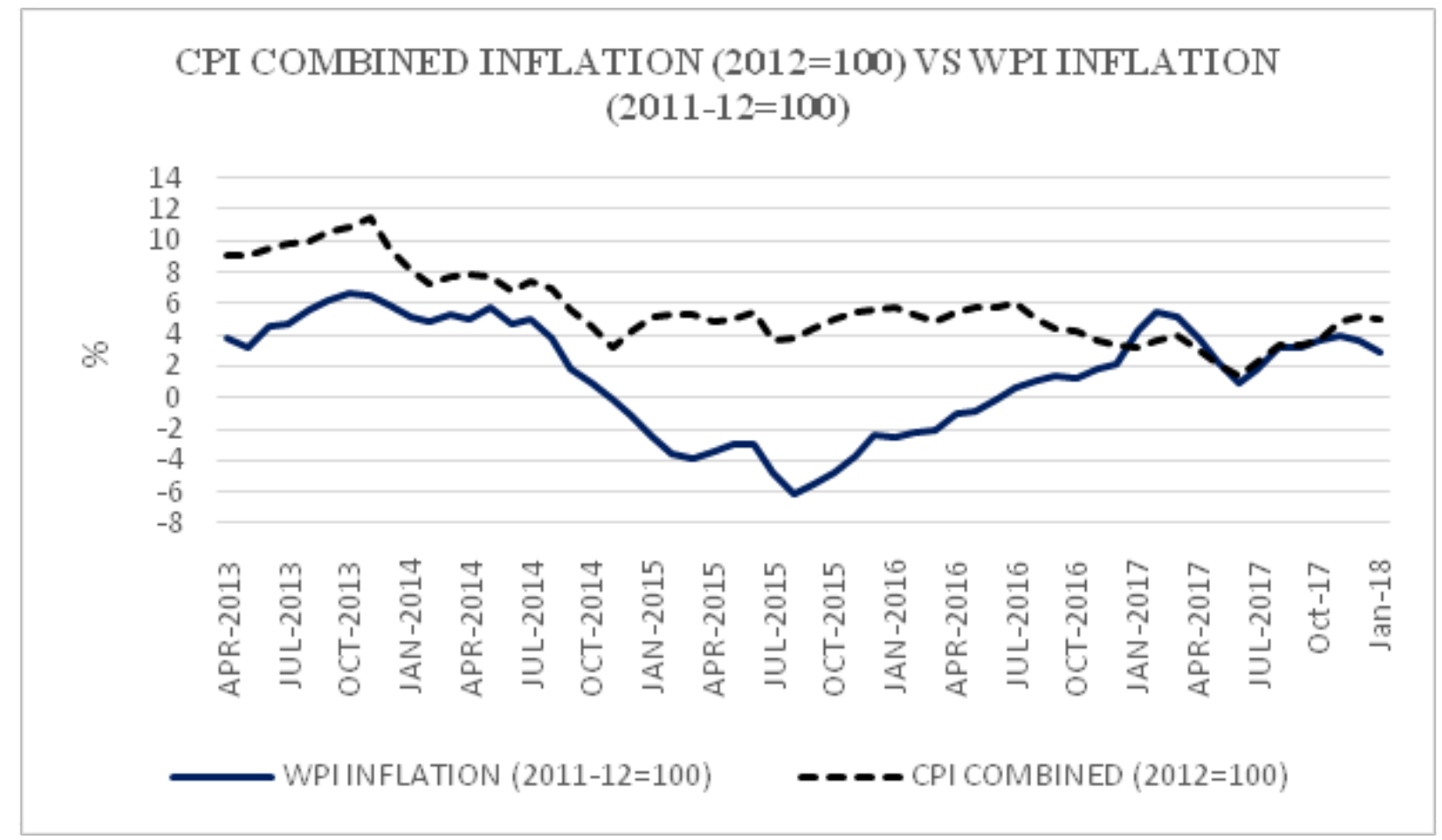

Figure 5. CPI Combined Inflation vs WPI Inflation

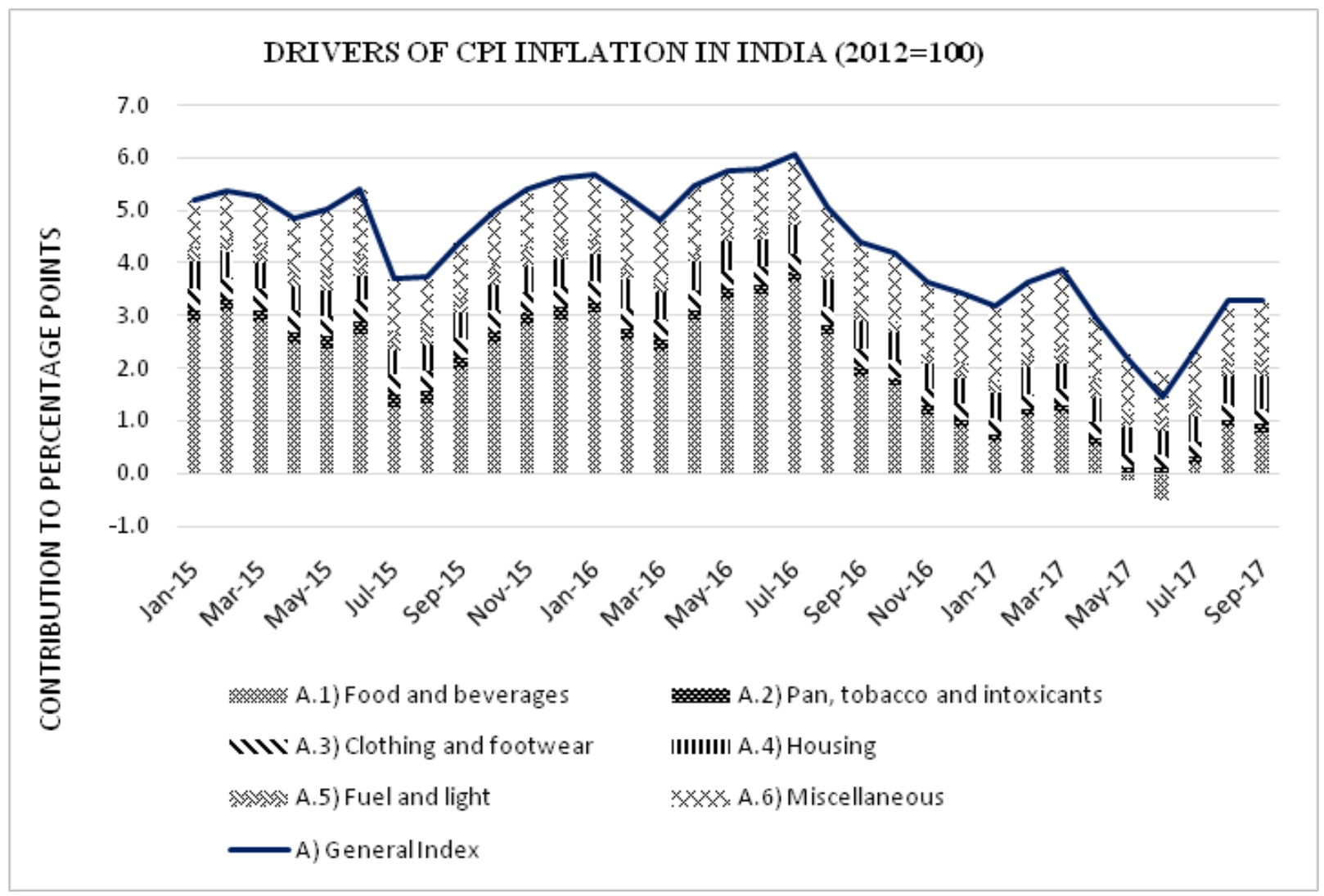

Figure 6. Drivers of CPI-Combined Inflation 
significant divergence between the two measures, fall in WPI can be attributed to a sharp fall in the commodity prices.

- Services such as education, medical care, recreation, which forms 28.3 percent of CPI has witnessed faster inflation over the last few years, resulting in sharper divergence with WPI which has a zero weight for services.

Table 3. Gap between CPI-IW and WPI Inflation based on Calendar Year Averages

\begin{tabular}{|c|c|c|c|}
\hline $\begin{array}{c}\text { Calendar } \\
\text { Year }\end{array}$ & $\begin{array}{c}\text { CPI-IW } \\
\text { Inflation }\end{array}$ & $\begin{array}{c}\text { WPI } \\
\text { Inflation }\end{array}$ & Gap \\
\hline 2007 & 6.5 & 4.9 & 1.6 \\
\hline 2008 & 8.1 & 8.7 & -0.5 \\
\hline 2009 & 10.8 & 2.4 & 8.5 \\
\hline 2010 & 12.0 & 9.6 & 2.5 \\
\hline 2011 & 8.9 & 9.5 & -0.6 \\
\hline 2012 & 9.3 & 7.5 & 1.8 \\
\hline 2013 & 10.9 & 6.3 & 4.6 \\
\hline 2014 & 6.3 & 3.8 & 2.6 \\
\hline 2015 & 5.9 & -2.7 & 8.6 \\
\hline 2016 & 4.9 & 2.0 & 2.9 \\
\hline
\end{tabular}

Source: Author's own calculation

\section{Review of Literature}

The studies analysing the relation between CPI and WPI using time series techniques have found some kind of stable relationship between the two series because of inter-linkages between the wholesale market and the retail market.

There are a number of studies which analyse the relationship between prices in the wholesale market and retail market for countries other than India. Some of these studies are Guthrie $\frac{17}{17}$, Jones (1986), Cushing and McGarvey ${ }^{3}$, Clark ${ }^{2}$ and Ghazali et al ${ }^{10}$, Ackay ${ }^{1}$.

Guthrie $e^{17}$ finds a relationship between changes in the WPI and changes in the CPI which can be described by a Pascal distributed lag model. This study was conducted for the US economy for January 1947 to December 1975.

Jones ${ }^{20}$ applied Wald test of Granger causality for the US economy and found evidence of bidirectional causality between WPI and CPI. Cushing and McGarvey ${ }^{23}$ found that wholesale price shocks had little or no permanent effect on the consumer price inflation. They indicate that feedback from WPI to CPI is greater than that from CPI to WPI and therefore, it can be concluded that WPI has high incremental power vis-à-vis CPI. On the contrary, Clark 2 concluded that even though pass-through effect from producer prices to consumer prices is weak but causality is unidirectional that runs from WPI to CPI. Ghazali et al. ${ }^{10}$ uses monthly data for CPI and Producer Price Index (PPI $)^{\mathrm{m}}$ at constant prices of 2000 for the period from January 1986 to April 2007 for Malaysia. They find that there is a unidirectional causality running from PPI to CPI. Topuz, Yazdifar and Sahadev 39 studied the relation between producer and consumer prices through a comparison between Turkey and the U.K.

There have been a number of studies which explore the same issue for the Indian economy. Samanta and Mitra ${ }^{32}$ applied cointegration and Granger causality tests on Indian inflation for two sub-periods (i) April 1991 to April 1995 and (ii) May 1995 to 1998. They find a stable long-run relationship between the two indices during 1991 to 1995, but not thereafter. Their results indicate strong evidence of growing divergence between the wholesale and consumer prices in India since May 1995. Shunmugam $\frac{35}{}$ finds evidence of cointegration over the entire period of study but in the pre- and post-liberalisation period evidence of cointegration was not found.

Mohanty ${ }^{24}$ conducts Granger Causality test in a Vector Auto-Regression (VAR) framework using monthly WPI and CPI. His results indicate that at the trend level CPI lag behind WPI by a month and there is a long-run cointegrating relationship between the two. Goyal and Tripathi ${ }^{11}$ provide justification for causality between consumer and producer prices ${ }^{\mathrm{n}}$. According to them, since consumer prices are a weighted average of the prices of domestic and imported consumption goods, and producer prices spill over into final consumer prices, wholesale price inflation should cause consumer price inflation ${ }^{33,34,37}$. Tiwari and Shahbaz ${ }^{38}$ found bidirectional causality between WPI and CPI indices in India in the short-as well as the long- run.

In a recent study, Das and George $e^{4}$ provide a comparative assessment of CPI and WPI in terms of their key characteristics, particularly on the method of compilation, distributional properties and measures of underlying inflation. They also try to reconcile sources of inflation divergence between CPI and WPI with particular emphasis on 2015-16.

In this paper, we test whether consumer price index measured by CPI-IW Granger causes Wholesale Price 
Index (WPI) in the Indian economy during the time period April 1996 to February 2017. We also check for casualty in the sub-period January 2008 to December 2013, which is identified as the longest period of divergence between the two indices. We check for the long-run cointegration between the indices in a Johansen and Juselieus $\frac{18,19}{19}$ framework and check for Granger Causality between them.

Our empirical model is specified as:

$$
\begin{aligned}
& \pi^{\mathrm{CPI}}=\mathrm{f}\left(\pi^{\mathrm{WPI}}, \mathrm{d} 1, \mathrm{~d} 2, \mathrm{~d} 3, \mathrm{~d} 4\right) \text { and } \\
& \pi^{\mathrm{WPI}}=\mathrm{f}\left(\pi^{\mathrm{CPI}}, \mathrm{d} 5, \mathrm{~d} 6\right)
\end{aligned}
$$

where $\pi^{\mathrm{CPI}}$ and $\pi^{\mathrm{WPI}}$ are CPI inflation and WPI inflation respectively. Dummies specified in Equation (1), namely, d1, d2, d 3 and $\mathrm{d} 4$ controls for different time periods characterised by low oil prices but rising food prices; drought and rising commodity prices; global financial crisis; and a recent period of falling food prices respectively. Dummies that enter Equation (2) controls for the 2008 global financial crisis and a recent decline in the commodity prices respectively.

\section{Data and Methodology}

\subsection{Data Sources}

In order to check for long-run relationship and causality between WPI and CPI-IW in India, we use monthly data covering a period from April 1996 to February 2017. WPI inflation is defined as year-on-year log difference of the WPI index with base 2004-05=100. CPI inflation is defined as year-on-year log difference of the CPI-IW index with base 2001=100. CPI-IW series showed seasonality and therefore, it was first desasonalised using ARIMA X-13 ${ }^{\circ}$ census procedure.

\subsection{Econometric Methodology}

\subsubsection{Tests for Non-Stationarity}

The first econometric step in estimation strategy is to test if the series are stationary. The classical regression model requires that the dependent and independent variables in a regression be stationary in order to avoid the problem of what Granger and Newbold ${ }^{16}$ called 'spurious regression'.

Several tests have been developed over time to test for the presence of a unit root. In this paper we focus on the
Dickey-Fuller GLS (DF-GLS) test ${ }^{\frac{8}{}}$. The power of this test is higher than the Augmented Dickey Fuller (ADF) test ${ }^{5,6}$.

\section{Table 4. Data Variables, Definitions and Sources}

\begin{tabular}{|c|c|c|}
\hline \multicolumn{3}{|c|}{ Data Variables, Definitions and Sources } \\
\hline Variable & Definition & Source \\
\hline $\mathrm{d} 1$ & $\begin{array}{c}\mathrm{d} 1=1 \text { for } 1998 \mathrm{M} 11 \text { to } \\
1999 \mathrm{M} 12 \text { and } 0 \text { otherwise }\end{array}$ & \\
\hline $\mathrm{d} 2$ & $\begin{array}{c}\mathrm{d} 2=1 \text { for } 2009 \mathrm{M} 7 \text { to } 2010 \\
\text { M1 and 0 otherwise }\end{array}$ & \\
\hline $\mathrm{d} 3$ & $\begin{array}{c}\mathrm{d} 3=1 \text { for } 2016 \mathrm{M} 8 \text { to } \\
2017 \mathrm{M} 2 \text { and } 0 \text { otherwise }\end{array}$ & \\
\hline $\mathrm{d} 4$ & $\begin{array}{c}\mathrm{d} 4=1 \text { for } 1997 \mathrm{M} 11 \text { to } \\
1998 \mathrm{M} 11 \text { and } 0 \text { otherwise }\end{array}$ & \\
\hline $\mathrm{d} 5$ & $\begin{array}{c}\mathrm{d} 5=1 \text { for } 2008 \mathrm{M} 6 \text { to } \\
2009 \mathrm{M} 6 \text { and } 0 \text { otherwise }\end{array}$ & \\
\hline $\mathrm{d} 6$ & $\begin{array}{c}\mathrm{d} 6=1 \text { for } 2014 \mathrm{M} 5 \text { to } \\
2015 \mathrm{M} 8 \text { and } 0 \text { otherwise }\end{array}$ & \\
\hline$\pi^{\mathrm{WPI}}$ & $\begin{array}{c}\text { year-on-year log difference } \\
\text { of the WPI index on base } \\
2004-05=100\end{array}$ & www.mospi.nic.in \\
\hline$\pi^{\mathrm{CPI}}$ & $\begin{array}{c}\text { year-on-year log difference } \\
\text { of the CPI index on base } \\
2001=100\end{array}$ & www.mospi.nic.in \\
\hline
\end{tabular}

\subsubsection{Johansen Cointegration Testing and Granger Causality}

If the variables are nonstationary, we test for the possibility of a cointegrating relationship using the Johansen and Juselius ${ }^{18,19}$ methodology. Cointegration refers to the longrun equilibrium relationship between the non-stationary variables that together yield a stationary linear combination ${ }^{28}$.

If the variables are cointegrated, we can construct a Vector Error-Correction Model (VECM) that captures the short-run dynamics of the variables in the system. According to Dua and Sen ${ }^{7}$ these dynamics represent the movements of at least some of the variables in the system in response to a deviation from the long-run equilibrium and these movements also ensure that the system returns to the long-run equilibrium.

"If two variables are cointegrated, i.e., they have a common trend, causality in the Granger (temporal) sense must exist in at least one direction $\frac{14,15}{}$. Granger causality analyses how much of the current variable $y_{t}$ can be explained by its own past values and tests whether adding lagged values of other variables $x_{t}$ can improve its forecasting performance. In the error-correction 
Table 5. Unit Root Test Results

DF-GLS Test: $\mathrm{H}_{0}$ : there exists a unit root in series

PP Test: $\mathrm{H}_{\mathbf{0}}$ : there exists a unit root in series

KPSS Test: $\mathrm{H}_{0}$ : series is stationary

SAMPLE: 1996 M4 - 2017 M2

\begin{tabular}{|c|c|c|c|c|c|c|}
\hline \multirow[t]{2}{*}{ Variable } & \multicolumn{2}{|c|}{ DF-GLS } & \multicolumn{2}{|c|}{ PP } & \multicolumn{2}{|c|}{ KPSS } \\
\hline & Level & First Difference & Level & $\begin{array}{c}\text { First } \\
\text { Difference }\end{array}$ & Level & $\begin{array}{c}\text { First } \\
\text { Difference }\end{array}$ \\
\hline$\Pi^{\mathrm{CPI}}$ & -1.43 & -10.99 & -2.68 & -10.91 & 0.2 & 0.05 \\
\hline$\Pi^{\mathrm{WPI}}$ & -2.33 & -5.62 & -2.97 & -10 & 0.17 & 0.02 \\
\hline C.V. 1\% & -3.46 & & -3.99 & & 0.21 & \\
\hline $5 \%$ & -2.922 & & -3.42 & & 0.14 & \\
\hline $10 \%$ & -2.63 & & -3.14 & & 0.12 & \\
\hline
\end{tabular}

Source: Author's own calculation

Table 6. Lag Selection Criteria

Dependent Variable: $\Pi^{\mathrm{CPI}}$

\begin{tabular}{|c|c|c|c|c|}
\hline Lag & LL & AIC & SBC & LR \\
\hline \multicolumn{5}{|c|}{$\begin{array}{c}\text { Endogenous Variables: } \Pi^{\mathrm{WPI}} \\
\text { Exogenous Variables: d1, d2, d3, d4 }\end{array}$} \\
\hline 0 & -1417.900 & -1425.900 & -1439.900 & 1813.100 \\
\hline 1 & -559.613 & -571.613 & -592.670 & 96.559 \\
\hline 2 & -525.559 & -541.559 & -569.634 & 28.451 \\
\hline 3 & -516.369 & -536.369 & -571.463 & $\mathbf{1 0 . 0 6 9}$ \\
\hline 4 & -511.331 & -535.334 & -577.447 & NA \\
\hline
\end{tabular}

( $\operatorname{Lag} 3$ is the most appropriate selection for VAR)

Source: Author's own calculation

framework, causality can be tested by a joint $\chi^{2}$ test between lags of $x_{t}$ and the error correction term.

\subsubsection{Impulse Responses and Variance Decomposition Analysis}

As compared to cointegration which gives the long-run relationship between variables and Granger causality, which shows the forecasting ability of other variables; Impulse Response Function (IRF) and Variance Decompositions (VDs) capture the dynamic relationship between variables. IRF traces the response of one standard error shock in the exogenous variable to the endogenous variable $e^{22}$. A shock to any variable in the system not only affects that variable directly but is also transmitted to other variables because of the dynamic structure of VAR. To analyse whether the response is statistically significant or not, bootstrapped confidence intervals are computed. In this paper the upper 97.5 percent and the lower 2.5 percentiles are used to test for the significance of the impulse response functions.

The Forecast Error Variance Decomposition (FEVD) decomposes variations in an endogenous variable into component shocks giving information about the relative importance of each random shock to the variable. The 
FEVD tells us the proportion of movement in a sequence due to its "own" shocks versus the shocks due to the other variables. Variance decompositions give the proportion of the h-periods-ahead forecast error variance of a variable that can be attributed to another variable.

We use the generalized impulse responses Pesaran and Shin and ${ }^{29}$ variance decompositions as compared to the orthogonalised impulse responses and variance decompositions because the latter depend upon the ordering of the variables. If the shocks to the respective equations in VAR are contemporaneously correlated, then the orthogonalised and generalised impulse responses may be quite different. On the other hand, if shocks are not contemporaneously correlated, then the two types of impulse responses may not be that different. As opposed to the orthogonalised decompositions, the generalised error variance decompositions can add up to more or less than 100 percent depending upon the strength of the covariance between different errors.

\section{Estimation Results}

The details of estimation results are listed in the order of their implementation in the following subsections.

\subsection{Results on Unit Root Tests}

First of all both measures of inflation are tested for the presence of a unit root using three tests: tests: DF-GLS, Phillips Perron (PP), Phillips ${ }^{30}$, Phillips and Perron ${ }^{31}$ Kwiatkowski-Phillips-Schmidt-Shin (KPSS). Table 5 shows that both WPI and CPI inflation are integrated of the order $1\{\mathrm{I}(1)\}$ for the entire time period 1996M4 to $2017 \mathrm{M} 2$. The series are also I(1) for the sub-period $2008 \mathrm{M} 1$ to $2013 \mathrm{M} 12^{\mathrm{p}}$. All the three tests show that both variables are non-stationary in levels but stationary in first differences.

A long-run relationship between the I(1) variables could be analysed by conducting the cointegration test.

\subsection{Cointegration Test}

For conducting the cointegration test, we need to examine two things: lag length of the model and inclusion of deterministic terms i.e., constant or trend in the underlying VAR.

In order to check the lag length, we employ the lag selection criteria $^{q}$ and also see that there is no remaining serial correlation to identify the correct model specification. For the inclusion of deterministic terms in VAR model, we work with different assumptions. Since most macroeconomic time series exhibit a linear trend, we capture this by using an intercept and no trend in the underlying VAR.

Using results given in Tables 6 and 7 we select the order of VAR as 3 and finally include only 2 lag in the VECM and only an intercept but no trend for both the models specified in Equations (1) and (2).

\section{Table 7. Selection Criteria}

Dependent Variable: $\Pi^{\text {WPI }}$

\begin{tabular}{|c|c|c|c|c|}
\hline Lag & LL & AIC & SBC & LR \\
\hline \multicolumn{5}{|c|}{$\begin{array}{l}\text { Endogenous Variables: } \Pi^{\mathrm{CPI}} \\
\text { Exogenous Variables: } \mathrm{d} 5, \mathrm{~d} 6\end{array}$} \\
\hline 0 & -1439.100 & -1443.1 & -1450.1 & 1788.43 \\
\hline 1 & -586.32 & -594.3 & -608.36 & 82.84 \\
\hline 2 & -552.00 & -564.0 & -585.09 & 14.45 \\
\hline 3 & -548.13 & -564.1 & -592.19 & 6.41 \\
\hline 4 & -544.93 & -564.9 & -600.02 & NA \\
\hline Lag & $\mathrm{LL}$ & AIC & SBC & LR \\
\hline
\end{tabular}

(Lag 3 is the most appropriate selection for VAR)

Source: Author's own calculation

Next we test for the presence of cointegration among the variables in both our empirical models given in Equation ( 1 and 2). Tables 8 to 10 show that the null hypothesis of no cointegration $(\mathrm{r}=0)$ is rejected at 5 percent level in both trace and maximum eigen-value tests. Further, the null hypothesis, that there is one cointegrating relation between variables $(\mathrm{r}=1)$ is not rejected by any of these tests. Since maximum eigenvalue test has a sharper alternative hypothesis as compared to the trace test, it is used to select the number of Cointegrating Vectors $(\mathrm{CVs})^{26}$.

On the basis of above results we conclude that there exists one $\mathrm{CV}$ in each case when CPI inflation is dependent variable and when WPI inflation is the dependent variable. The result holds for the whole time period 1996M4 to 2017M2 and sub-period 2008M1 to $2013 \mathrm{M} 12$.

\subsection{Long Run Cointegrating Equation}

Various alternative specifications of the empirical models given in Equation (1) are estimated to arrive at the final 
Table 8. Maximal Eigenvalue Test Statistic for CPI Inflation (1996M4 to 2017M2)

$\mathrm{H}_{0}$ : There exists $\mathrm{r}$ CVs.

$\mathrm{H}_{1}$ : There exists n CVs.

\begin{tabular}{|c|c|c|c|c|c|c|}
\hline $\mathbf{H}_{\mathbf{0}}$ & $\mathbf{H}_{\mathbf{1}}$ & Statistic & Critical Values (95\%) & Critical Values (90\%) & Results & No. of CV \\
\hline \multicolumn{7}{|c|}{ MODEL: $\Pi^{\mathrm{CPI}}=\mathrm{f}\left(\Pi^{\mathrm{WPI}}, \mathrm{d} 1, \mathrm{~d} 2, \mathrm{~d} 3, \mathrm{~d} 4\right)$} \\
\hline $\mathrm{r}=0$ & $\mathrm{r}=1$ & 25.9461 & 14.88 & 12.98 & ${\text { Reject } \mathrm{H}_{0}}^{1}$ \\
\hline $\mathrm{r}<=1$ & $\mathrm{r}=2$ & 0.43369 & 8.07 & 6.5 & Do Not Reject $\mathrm{H}_{0}$ & \\
\hline
\end{tabular}

Source: Author's own calculation

Table 9. Trace Test Statistic for CPI Inflation (1996M4 to 2017M2)

$\mathrm{H}_{0}$ : There exists $\mathrm{r}$ CVs.

$\mathrm{H}_{1}$ : There exists n CVs.

\begin{tabular}{|c|c|c|c|c|c|c|}
\hline $\mathbf{H}_{\mathbf{0}}$ & $\mathbf{H}_{\mathbf{1}}$ & Statistic & $\begin{array}{c}\text { Critical Values } \\
\mathbf{( 9 5 \% )}\end{array}$ & $\begin{array}{c}\text { Critical } \\
\text { Values (90\%) }\end{array}$ & Results & No. of CV \\
\hline MODEL: $\Pi^{\mathrm{CPI}}=\mathrm{f}\left(\Pi^{\mathrm{WPI}}, \mathrm{d} 1, \mathrm{~d} 2, \mathrm{~d} 3, \mathrm{~d} 4\right)$ \\
\hline $\mathrm{r}=0$ & $\mathrm{r}>=1$ & 32.0915 & 17.86 & 15.75 & Reject $\mathrm{H}_{0}$ & 1 \\
\hline $\mathrm{r}<=1$ & $\mathrm{r}=2$ & 6.1453 & 8.07 & 6.5 & $\begin{array}{c}\text { Do Not } \\
\text { Reject } \mathrm{H}_{0}\end{array}$ \\
\end{tabular}

Source: Author's own calculation

Table 10. Cointegration Test Statistic for WPI Inflation (1996M4 to 2017M2)

\begin{tabular}{|c|c|c|c|c|c|c|}
\hline \multicolumn{7}{|c|}{ Maximal Eigenvalue Test Statistic } \\
\hline $\mathbf{H}_{0}$ & $\mathbf{H}_{1}$ & Statistics & $\begin{array}{c}\text { Critical Values } \\
(95 \%)\end{array}$ & $\begin{array}{c}\text { Critical } \\
\text { Values }(90 \%)\end{array}$ & RESULTS & $\begin{array}{c}\text { No. of } \\
\text { CV }\end{array}$ \\
\hline \multicolumn{7}{|c|}{ MODEL: $\Pi^{\mathrm{WPI}}=\mathrm{f}\left(\Pi^{\mathrm{CPI}}, \mathrm{d} 5, \mathrm{~d} 6\right)$} \\
\hline$r=0$ & $r=1$ & 19.62 & 14.88 & 12.98 & & \\
\hline $\mathrm{r}<=1$ & $\mathrm{r}=2$ & 6.58 & 8.07 & 6.5 & & \\
\hline \multicolumn{7}{|c|}{ Trace Test Statistic } \\
\hline $\mathrm{H}_{0}$ & $\mathrm{H}_{1}$ & Statistics & $\begin{array}{c}\text { Critical Values } \\
(95 \%)\end{array}$ & $\begin{array}{c}\text { Critical } \\
\text { Values }(90 \%)\end{array}$ & RESULTS & $\begin{array}{l}\text { No. of } \\
\text { CV }\end{array}$ \\
\hline \multicolumn{7}{|c|}{ MODEL: $\Pi^{\mathrm{CPI}}=\mathrm{f}\left(\Pi^{\mathrm{WPI}}, \mathrm{d} 5, \mathrm{~d} 6\right)$} \\
\hline$r=0$ & $\mathrm{r}>=1$ & 31.19 & 17.86 & 15.75 & & \\
\hline $\mathrm{r}<=1$ & $r=2$ & 6.58 & 8.07 & 6.5 & & \\
\hline
\end{tabular}

Source: Author's own calculation 
Table 11. Estimated VECM for CPI Inflation

\begin{tabular}{|c|c|c|c|}
\hline \multicolumn{4}{|c|}{ Estimated VECM: Sample: 1996 M4 to 2017 M2 } \\
\hline \multicolumn{4}{|l|}{ Normalized Variable: $\Pi^{\mathrm{CPI}}$} \\
\hline Endogenous Variable: & Coefficient & SE & t-statistic \\
\hline$\Pi^{\mathrm{WPI}}$ & 0.05 & 0.23 & 0.217 \\
\hline \multicolumn{4}{|c|}{ Exogenous Variable: $\mathrm{d} 1, \mathrm{~d} 2, \mathrm{~d} 3, \mathrm{~d} 4$} \\
\hline ECM term & -0.098 & 0.019 & -5.109 \\
\hline \multicolumn{4}{|c|}{ Estimated VECM: Sample: 2008 M1 to 2013 M12 } \\
\hline \multicolumn{4}{|l|}{ Normalized Variable: $\Pi^{\mathrm{CPI}}$} \\
\hline Endogenous Variable: & Coefficient & SE & t-statistic \\
\hline$\Pi^{\mathrm{WPI}}$ & -0.08 & 0.25 & -0.32 \\
\hline \multicolumn{4}{|l|}{ Exogenous Variable: $\mathrm{d} 3$} \\
\hline ECM term & -0.22 & 0.05 & -3.97 \\
\hline
\end{tabular}

Source: Author's own calculation

cointegrating equation ${ }^{\mathrm{r}}$. Tables 11 and 12 report the final selected cointegration equations on the basis of certain diagnostic tests mentioned above. Firstly, we take CPI inflation as the dependent variable (Equation (1)) and the cointegrating equation is normalised with respect to CPI inflation for both the time periods. Then we estimate Equation (2), where WPI inflation is the dependent variable and cointegrating equation is normalised with respect to WPI inflation.

The estimated VEC for the model is given below:

For the entire period 1996M4 to 2017M2, the sign of WPI is in line with the economic theory which suggests that any rise in wholesale price inflation in the economy has a positive impact on the retail price inflation. Furthermore, the ECM term is negative, less than one and is statistically significant. This implies that in the long-run any deviation from the equilibrium path will be closed in each time period. Negative sign implies that if CPI inflation is high today, then it would fall till the equilibrium is restored back. The magnitude of the ECM term suggests that after a shock is administered, it takes a long time for adjustment to take place. In particular, long term CPI inflation closes by about 10 percent in each time period for the entire sample period. For the sub-period 2008M1 to 2013M12, the sign of WPI is not in line with the theory and suggest that an increase in WPI inflation leads to a decline in CPI inflation. This suggests divergence between the two series during the sub-period. The ECM term is negative, less than one and is statistically significant. The magnitude of the ECM term show that long-term CPI inflation closes by about 22 percent in each time period for the sub-period.

The short-run dynamics of Equation (1) for the entire period are explained with the help of the following equation:

$$
\begin{aligned}
D\left(\Pi^{C P I}\right)= & -0.098 E C M_{t-1}+0.119 D\left(\Pi_{t-1}^{C P I}\right)+0.066 D\left(\Pi_{t-1}^{W P I}\right) \\
& -1.0234 d_{1}+1.14 d_{2}-0.68 d_{3}+1.35 d_{4}+0.58 \\
D\left(\Pi^{W P I}\right)= & -0.098 E C M_{t-1}+0.119 D\left(\Pi_{t-1}^{C P I}\right)+0.066 D\left(\Pi_{t-1}^{W P I}\right)-1.0234 d_{1} \\
+ & 1.14 d_{2}-0.68 d_{3}+1.35 d_{4}+0.58
\end{aligned}
$$

\begin{tabular}{|c|c|c|c|}
\hline \multicolumn{4}{|c|}{ Estimated VECM: Sample: 1996 M4 to 2017 M2 } \\
\hline \multicolumn{4}{|c|}{ Normalized Variable: $\Pi^{\text {WPI }}$} \\
\hline Endogenous Variable: & Coefficient & SE & t-statistic \\
\hline$\Pi^{\mathrm{CPI}}$ & 0.14 & 0.30 & 0.462 \\
\hline \multicolumn{4}{|c|}{ Exogenous Variable: d5, d6 } \\
\hline ECM term & -0.071 & 0.017 & -4.354 \\
\hline \multicolumn{4}{|c|}{ Estimated VECM: Sample: 2008 M1 to 2013 M12 } \\
\hline \multicolumn{4}{|l|}{ Normalized Variable: $\Pi^{\mathrm{WPI}}$} \\
\hline Endogenous Variable: & Coefficient & SE & t-statistic \\
\hline$\Pi^{\mathrm{CPI}}$ & -1.34 & 0.762 & -1.76 \\
\hline \multicolumn{4}{|l|}{ Exogenous Variable: d5 } \\
\hline ECM term & -0.070 & 0.023 & -2.99 \\
\hline
\end{tabular}

where

$$
E C M_{t-1}=\Pi^{C P I}-0.05 \Pi^{W P I}
$$

Table 12. Estimated VECM for WPI Inflation

Source: Author's own calculation 
The above equation shows that for the entire period $1996 \mathrm{M} 4$ to $2017 \mathrm{M} 2$ changes in CPI inflation is affected by one period lagged value of both CPI and WPI inflation in the short-run. For the sub-period 2008M1 to 2013M12 the short-run dynamics are explained by the equation given below:

$$
\begin{aligned}
D\left(\Pi^{C P I}\right) & =-0.22 E C M_{t-1}+0.017 D\left(\Pi_{t-1}^{C P I}\right) \\
& +0.149 D\left(\Pi_{t-1}^{W P I}\right)+1.03 d_{3}+0.211
\end{aligned}
$$

where

$$
E C M_{(t-1)}=\Pi^{C P I}+0.76 \Pi^{W P I}
$$

This equation shows that during the sub-period 15 units of change in CPI inflation is explained by change in one period lagged value of WPI inflation. The impact in both the periods is statistically significant.

The estimated VEC for the model $\pi^{W P I}=f\left(\pi^{C P I}, d 5, d 6\right)$ is given as:

Results suggest that any rise in CPI inflation leads to a rise in WPI inflation which is in accordance with the economic theory. The ECM term in this model is also negative, less than one and is statistically significant.

The results for the sub-period 2008M1 to 2013M12 suggest that both WPI inflation and CPI inflation move in an opposite direction. This could be due to a long period of divergence between CPI and WPI inflation during this time in the Indian economy. ECM term is still negative, less than one and statistically significant implying that even in this period the system is stable for both the models.

The short-run dynamics of Equation (2) estimated for the whole time period are given by the following equation

$$
\begin{aligned}
D\left(\Pi^{W P I}\right) & =-0.072 E C M_{t-1}-0.056 D\left(\Pi_{t-1}^{C P I}\right) \\
& +0.427 D\left(\Pi_{t-1}^{W P I}\right)-0.0397 d_{5}-0.773 d_{6}+0.366
\end{aligned}
$$

where

$$
E C M_{t-1}=\Pi^{W P I}-0.14 \Pi^{C P I}
$$

Short-run equation for the sub-period is given as:

$$
\begin{aligned}
D\left(\Pi^{W P I}\right)= & -0.070 E C M_{t-1}-0.074 D\left(\Pi_{t-1}^{C P I}\right) \\
& +0.568 D\left(\Pi_{t-1}^{W P I}\right)-0.566 d_{5}+1.50
\end{aligned}
$$

where

$$
E C M_{t-1}=\Pi^{W P I}+1.35 \Pi^{C P I}
$$

\begin{tabular}{|c|c|c|c|c|}
\hline $\mathbf{H}_{0}$ & Sample Period & No. of Lags & $\begin{array}{c}\chi^{2} \text { Calculated } \\
\text { (p-value in parenthesis) }\end{array}$ & Conclusion \\
\hline \multicolumn{5}{|c|}{$\pi^{C P I}=f\left(\pi^{W P I}\right)$} \\
\hline $\begin{array}{l}\text { WPI inflation does not Granger } \\
\text { cause CPI inflation }\end{array}$ & $\begin{array}{l}\text { 1996M4 to } \\
2017 \mathrm{M} 2\end{array}$ & 2 & $16.02(0.00)$ & Reject $\mathrm{H}_{0}$ \\
\hline $\begin{array}{l}\text { WPI inflation does not Granger } \\
\text { cause CPI inflation }\end{array}$ & $\begin{array}{l}2008 \mathrm{M} 1 \text { to } \\
2013 \mathrm{M} 12\end{array}$ & 2 & $10.7(0.03)$ & Reject $\mathrm{H}_{0}$ at $3 \%$ \\
\hline \multicolumn{5}{|c|}{$\pi^{W P I}=f\left(\pi^{C P I}\right)$} \\
\hline $\begin{array}{l}\text { CPI inflation does not Granger } \\
\text { cause WPI inflation }\end{array}$ & $\begin{array}{l}\text { 1996M4 to } \\
2017 \mathrm{M} 2\end{array}$ & 2 & $19.95(0.00)$ & Reject $\mathrm{H}_{0}$ \\
\hline $\begin{array}{l}\text { CPI inflation does not Granger } \\
\text { cause WPI inflation }\end{array}$ & $\begin{array}{l}2008 \mathrm{M} 1 \text { to } \\
2013 \mathrm{M} 12\end{array}$ & 2 & $9.3(0.04)$ & Reject $\mathrm{H}_{0}$ at $4 \%$ \\
\hline
\end{tabular}

The short-run dynamics suggest that change in one period lagged value of CPI inflation leads to 6 units of change in WPI inflation during the entire period and 7 units during the sub-period. The impact in both the periods is statistically significant.

Hence, the effect of WPI inflation on CPI inflation is more pronounced.

Table 13. Granger Causality 


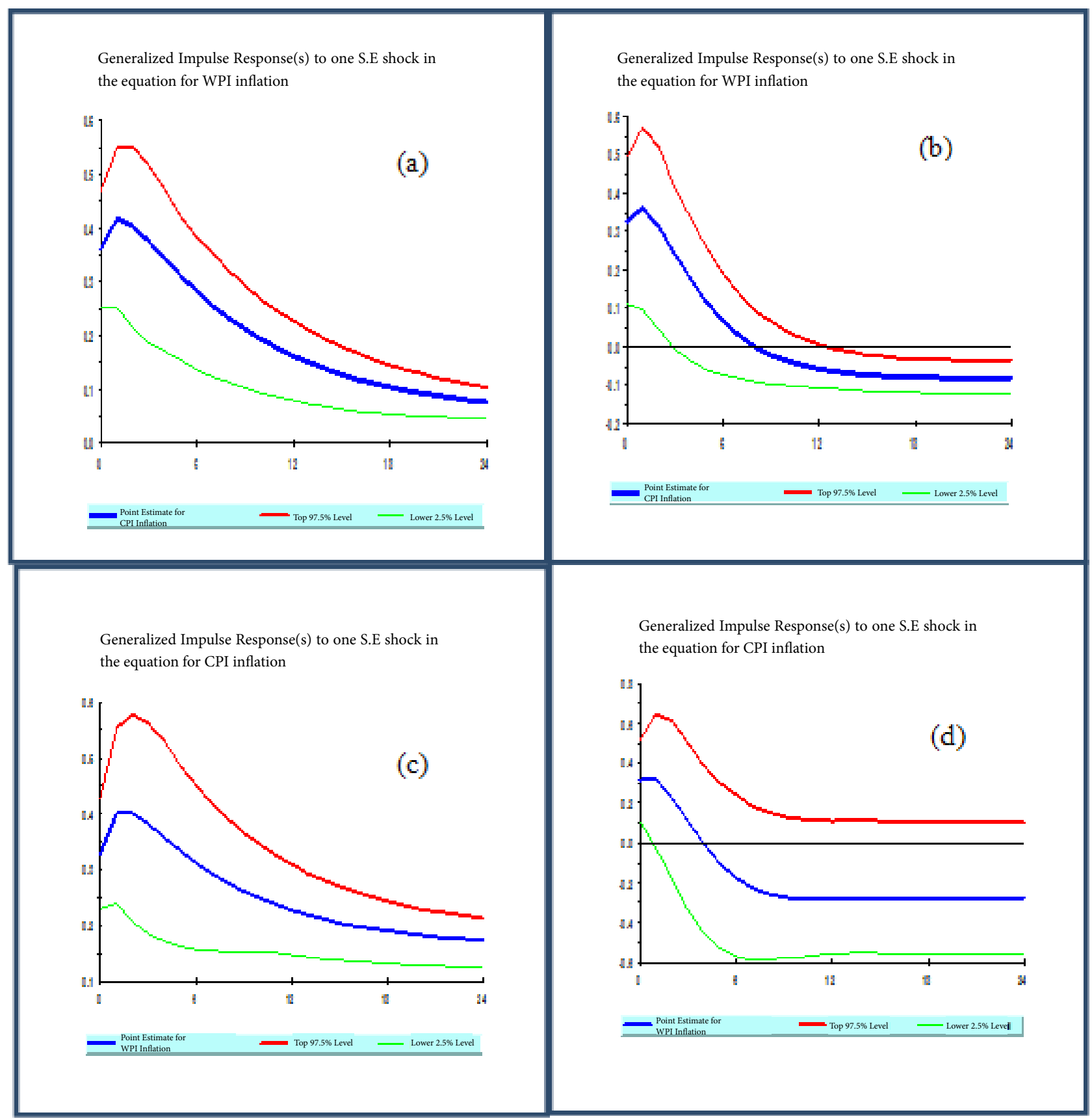

Figure 7. Generalized Impulse Response Functions

\subsection{Granger Causality Results Based on VECM}

The VECM framework is also used to test whether independent variables individually as well as jointly granger cause both the CPI inflation and WPI inflation. This is accomplished by testing for the joint significance of the lagged terms of each variable along with the error correction term. This joint test of significance is the Wald test which is distributed as a chi-square statistic with degrees of freedom equal to the number of lags imposed in the model. Table 13 reveals that the null hypothesis of no granger causality is strongly rejected in each case.

\subsection{Generalised Impulse Response Function (GIRF)}

Figure 7 (a) and (b) gives GIRF of the response of CPI inflation to a one standard deviation shock in WPI inflation for both the entire period and sub-period. The 
Table 14. Forecast Error Variance Decomposition

Sample: 1996M4 to 2017M12

\begin{tabular}{|c|c|c|}
\hline \multicolumn{3}{|c|}{ CPI Inflation } \\
\hline Horizon & $\pi^{\mathrm{CPI}}$ & $\pi^{\mathrm{WPI}}$ \\
\hline 0 & 82.81 & 17.19 \\
\hline 6 & 79.67 & 20.33 \\
\hline 12 & 78.32 & 21.68 \\
\hline 24 & 77.06 & 22.94 \\
\hline
\end{tabular}

\section{Sample: 2008M1 to 2013M12}

\begin{tabular}{|c|c|c|}
\hline \multicolumn{3}{|c|}{ CPI Inflation } \\
\hline Horizon & $\pi^{\mathrm{CPI}}$ & $\pi^{\mathrm{WPI}}$ \\
\hline 0 & 87.88 & 12.12 \\
\hline 6 & 82.08 & 17.92 \\
\hline 12 & 82.12 & 17.88 \\
\hline 24 & 79.89 & 20.11 \\
\hline
\end{tabular}

Source: Author's own calculation

significance of IR is determined through the bootstrapped confidence intervals where we consider upper 97.5 percent and lower 2.5 percentiles.

One standard deviation shock to WPI inflation affect CPI inflation positively in the short run and then the effect converges back towards equilibrium. However, during the sub-period, the response of CPI inflation to shock in WPI inflation is positive in the short run but it turns negative after some months. The effect is significant as shown by bootstrapped confidence intervals for both time periods.

Figure 7 (c) and (d) gives GIRF of the response of WPI inflation to a one standard deviation shock in CPI inflation for the entire time period as well as for the sub period. During the sub-period, the impact is positive in the short-run but it turns negative after about 6 months. IR's are also not significant for the same time period.

\subsection{Forecast Error Variance Decomposition (FEVD)}

Table 14 shows the FEVD for Equation (1) and (2). It explains that at the end of a forecast horizon of 24 months about 23 percent of variation in CPI inflation is explained by WPI inflation during the entire period. The Variation remains the same when CPI inflation is used as the independent variable (Equation (2)).

\begin{tabular}{|c|c|c|}
\hline \multicolumn{3}{|c|}{ WPI Inflation } \\
\hline Horizon & $\pi^{\mathrm{WPI}}$ & $\pi^{\mathrm{CPI}}$ \\
\hline 0 & 80.95 & 19.05 \\
\hline 6 & 82.84 & 17.16 \\
\hline 12 & 80.72 & 19.28 \\
\hline 24 & 76.88 & 23.12 \\
\hline
\end{tabular}

\begin{tabular}{|c|c|c|}
\hline \multicolumn{3}{|c|}{ WPI Inflation } \\
\hline Horizon & $\pi^{\text {WPI }}$ & $\pi$ cPI \\
\hline 0 & 84.94 & 15.06 \\
\hline 6 & 95.13 & 4.87 \\
\hline 12 & 91.26 & 8.74 \\
\hline 24 & 86.35 & 13.65 \\
\hline
\end{tabular}

FEVD during the sub-period 2008-2013 show that WPI explains 20 percent of variation in CPI but CPI explains only 13 percent variation in WPI. FEVD's indicates the importance of a variable in determining changes in the other variable, but they do not explain the direction or nature of such change. Hence, the analysis on GIRF discussed in the previous section should be used along with the discussion on FEVD to arrive at any conclusions.

\section{Summary and Conclusions}

In this paper we begin by discussing that price stability is an important objective of any macroeconomic policy formulation. In this decision, it is imperative to know which measure of inflation is chosen as a targeting instrument by the central bank. In India, inflation is measured using various price indices. The indices that are primarily chosen for any analysis are the Wholesale Price Index (WPI) and the Consumer Price Index (CPI). Retail prices measured by CPI in India are compiled for four different segments of the population that is industrial worker, agricultural labour, rural labour and urban nonmanual employees. Until recently, WPI was considered as the measure of headline inflation because it was available at a higher frequency. However, price of services are not 
included in this measure. Moreover, internationally for all analysis pertaining to economic policymaking, $\mathrm{CPI}$ is considered to be more relevant than WPI.

Recently, CSO started releasing new Consumer Price Indices with base $2010=100$ for all-India and states and union territories since January 2011. This new index of CPI is known as CPI-Combined and it includes price indices separately for rural and urban population. This paper uses CPI-IW as the relevant indicator, owing to data limitations with regard to the new CPI index.

Stylized facts and illustration used in the paper show that both CPI-IW and WPI inflation have significantly diverged from each other during different time periods. This divergence is attributed both to different weightage of food in both the indices and inclusion of services in the CPI index.

In order to analyse the long-run relationship between WPI and CPI inflation in India we conduct a granger causality test in a VAR framework by using monthly data from 1996M4 to 2017M2. This exercise is also carried for the sub-period $2008 \mathrm{M} 1$ to $2013 \mathrm{M} 12$, as this coincides with the effects of global financial crisis.

Our results suggest that both WPI and CPI-IW inflation Granger Cause each other and it is bidirectional causality. The cointegrating equations show that the signs of the coefficient are in line with the economic theory, for the entire time period but they are opposite for the subperiod. This suggests a possible divergence between the two series during 2008-2013. Both the series explain a significant variation in the other series except for the subperiod when CPI-IW inflation explains lesser variation in WPI inflation.

It has also been observed that WPI inflation is more responsive to changes in fuel prices whereas CPI-IW inflation is more responsive to changes in food prices. Since, variability in food and fuel prices increased during 2009-2013, it may provide a reasonable explanation for divergence between the two indices. However, both the series Granger cause each other even when a divergent pattern is observed between the two.

\section{Acknowledgment}

This study is based on my PhD work at the Delhi School of Economics, University of Delhi. I sincerely thank Prof. Pami Dua for her valuable comments and guidance throughout the work.

\section{References}

1. Akcay $\mathrm{S}$. The causal relationship between producer price index and consumer price index: Empirical evidence from selected European countries. International Journal of Economics and Finance. 2011; 3(6):227. https://doi. org/10.5539/ijef.v3n6p227

2. Clark TE. Do producer prices lead consumer prices? Economic Review-Federal Reserve Bank of Kansas City. 1995; 80(3):25.

3. Cushing MJ, McGarvey MG. Feedback between wholesale and consumer price inflation: A re-examination of the evidence. Southern Economic Journal. 1990; 1059-72. https://doi.org/10.2307/1059891

4. Das P, George AT. Comparison of consumer and wholesale prices indices in India: An analysis of properties and sources of divergence. eSocialSciences; 2017.

5. Dickey DA, Fuller WA. Distribution of the estimators for autoregressive time series with a unit root. Journal of the American Statistical Association. 1979; 74(366a):427-31. https://doi.org/10.1080/01621459.1979.10482531

6. Dickey DA, Fuller WA. Likelihood ratio statistics for autoregressive time series with a unit root. Econometrica: Journal of the Econometric Society. 1981; 1057-72. https:// doi.org/10.2307/1912517

7. Dua P, Sen P. Capital flows and exchange rates: The Indian experience. Indian Economic Review. 2013; 189-219.

8. Elliot BE, Rothenberg TJ, Stock JH. Efficient tests of the unit root hypothesis. Econometrica. 1996; 64(8):13-36.

9. Engle RF, Granger CW. Co-integration and error correction: Representation, estimation, and testing. Econometrica: Journal of the Econometric Society. 1987; 251-76. https:// doi.org/10.2307/1913236

10. Ghazali MF, Yee OA, Muhammad MZ. Do producer prices cause consumer prices? Some empirical evidence. International Journal of Business and Management. 2009; 3(11):78. https://doi.org/10.5539/ijbm.v3n11p78

11. Goyal A, Tripathi S. Extracting information on inflation from consumer and wholesale prices and the NKE aggregate supply curve. Indira Gandhi Institute of Development Research (IGIDR); 2010.

12. Government of India. Consumer price index, changes in revised series (Base Year 2012=100). Ministry of Statistics and Program Implementation, Central Statistics Office, National Accounts Division, Prices and Cost of Living Unit; 2015.

13. Government of India. Manual on wholesale Price Index (Base: 2011-12=100). Office of the Economic Advisor, Department of Industrial Policy and Promotion, Ministry of Commerce and Industry, New Delhi; 2017.

14. Granger CW. Developments in the study of cointegrated economic variables. Oxford Bulletin of Economics and 
Statistics. 1986; 48(3):213-28. https: // doi. org/ 10.1111/ j.1468 - 0084.1986. mp48003002. $\mathrm{x}$

15. Granger CW. Some recent development in a concept of causality. Journal of Econometrics. 1988; 39(1-2):199-211. https://doi.org/10.1016/0304-4076\%2888\%2990045-0

16. Granger CW, Newbold P. Spurious regressions in econometrics. Journal of Econometrics. 1974; 2(2):111-20. https://doi.org/10.1016/0304-4076\%2874\%2990034-7

17. Guthrie RS. The relationship between wholesale and consumer prices. Southern Economic Journal. 1981; 104655. https://doi.org/10.2307/1058161

18. Johansen S. Determination of cointegration rank in the presence of a linear trend. Oxford Bulletin of Economics and Statistics. 1992; 54(3):383-97. https://doi. org/10.1111/j.1468-0084.1992.tb00008.x

19. Johansen S, Juselius K. Maximum likelihood estimation and inference on cointegration- with applications to the demand for money. Oxford Bulletin of Economics and statistics. 1990; 52(2):169-210. https://doi.org /10.1111/ j.1468-0084.1990.mp52002003.x

20. Jones JD. Consumer prices, wholesale prices, and causality. Empirical Economics. 1986; 11(1):41-55. https:// doi.org/ 10.1007/ BF01978144

21. Juselius K. Testing structural hypotheses in a multivariate cointegration analysis of the PPP and the UIP for UK. Journal of Econometrics. 1992; 53(1-3):211-44. https://doi. org/10.1016/0304-4076\%2892\%2990086-7

22. Koop G, Pesaran MH, Potter SM. Impulse response analysis in nonlinear multivariate models. Journal of Econometrics. 1996; 74(1):119-47. https:// doi.org/ 10.1016/ 0304-4076 2895 2901753-4

23. McGarvey MG. US evidence on linear feedback from money growth shocks to relative price changes, 1954 to 1979. The Review of Economics and Statistics. 1985; 67580. https://doi.org/10.2307/1924813

24. Mohanty D. Inflation dynamics in India: issues and concerns. RBI Bulletin; 2010.

25. Ng S, Perron P. Lag length selection and the construction of unit root tests with good size and power. Econometrica. 2001; 69(6):1519-54. https:// doi.org/ 10.1111/ 1468-0262. 00256

26. Osterwald-Lenum M. A note with quantiles of the asymptotic distribution of the maximum likelihood cointegration rank test statistics. Oxford Bulletin of Economics and Statistics, 1992; 54(3):461-72. https://doi. org/10.1111/j.1468-0084.1992.tb00013.x

27. Patnaik I, Shah A, Veronese G. How should inflation be measured in India? Economic and Political Weekly. 2011; 55-64.

28. Pesaran MH, Shin Y, Smith RJ. Testing for the Existence of a long-run relationship (No. 9622). Faculty of Economics, University of Cambridge; 1996.
29. Pesaran HH, Shin Y. Generalized impulse response analysis in linear multivariate models. Economics letters. 1998; 58(1):17-29. https:// doi.org/ 10.1016/ S0165-1765 2897 2900214-0

30. Phillips PC. Time series regression with a unit root. Econometrica: Journal of the Econometric Society. 1987; 277-301. https://doi.org/10.2307/1913237

31. Phillips PC, Perron P. Testing for a unit root in time series regression. Biometrika. 1988; 75(2):335-46. https://doi. org/10.1093/biomet/75.2.335

32. Samanta GP, Mitra S. Recent divergence between wholesale and consumer prices in India- A statistical exploration. RBI Occasional Papers. 1998; 19(4).

33. Shahbaz M, Nasir NM. Producer and consumer prices nexus: ARDL bounds testing approach. International Journal of Marketing Studies. 2009; 1(2):78. https://doi. org/10.5539/ijms.v1n2p78

34. Shahbaz M, Wahid AN, Haider A. Empirical psychology between wholesale price and consumer price indices: The case of Pakistan. The Singapore Economic Review. 2010; 55(03):537-51. https://doi.org/10.1142/ S0217590810003882

35. Shunmugam V. Causality links between CPI and WPI-An econometric exploration. Multi Commodity Exchange of India Ltd; 2009. PMid:19821725 PMCid:PMC2832653

36. Subbarao D. Inaugural address: 3rd annual statistics day conference. Reserve Bank of India Bulletin; 2010.

37. Tiwari AK. Causality between wholesale price and consumer price indices in India: An empirical investigation in the frequency domain. Indian Growth and Development Review. 2012; 5(2):151-72. https://doi. org/10.1108/17538251211268071

38. Tiwari AK, Shahbaz M. Modelling the relationship between whole sale price and consumer price indices: Cointegration and causality analysis for India. Global Business Review. 2013; 14(3):397-411. https://doi. org/10.1177/0972150913496784

39. Topuz YV, Yazdifar H, Sahadev S. The relation between the producer and consumer price indices: A two-country study. Journal of Revenue and Pricing Management, 2017; 1-9. https://doi.org/10.1057/s41272-017-0125-x

\section{Notes:}

${ }^{\mathrm{b}}$ CPI-UNME has been discontinued since April 2010.

${ }^{\mathrm{c}}$ Measure of inflation which is observed by the central bank for policy formulation.

accoun

d This study is conducted on monthly data and the time period under consideration is April 1996 to February 2017. The new series with base 2011-12 was released in May 2017. Hence the study used older WPI series with base 2004-05. 


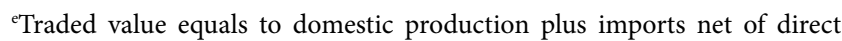
imports reaching factories minus direct exports.

${ }^{\mathrm{f}}$ GOI (2017), Manual on wholesale Price Index (Base: 2011-12=100). Office of the Economic Advisor, Department of Industrial Policy and Promotion, Ministry of Commerce and Industry, New Delhi, p.5.

${ }^{\mathrm{g}}$ Price relatives $=(\text { current } \text { price } / \text { base price })^{\star} 100$

${ }^{\mathrm{h}} \mathrm{I}=\Sigma(\mathrm{Ii} \times \mathrm{Wi}) / \Sigma \mathrm{Wi}$ Where, $\Sigma$ represents the summation operation; $\mathrm{I}=$ Index Number of wholesale prices of a subgroup/group/major group/All commodities; $\mathrm{Wi}$ = weight assigned; $\mathrm{I}=$ = Index of the ith item/sub- group/ group/major group.

${ }^{\mathrm{i} C P I-U N M E ~(1984-85=100), C P I-R L ~}(1986-87=100), C P I-A L \quad(1986-$ $87=100)$

i As given in the CPI (2012=100) manual released by CSO (pp. 20-21), Laspeyres index formula can be written as:

$$
P_{L}=\frac{\sum_{i=1}^{n} P_{i}^{t} q_{i}^{0}}{\sum_{i=1}^{n} p_{i}^{0} q_{i}^{0}}
$$

where

$p_{i}^{t}=$ price of ith term in the current time ' $t^{\prime} ; p_{i}^{t}=$ price for ith item and $q_{i}^{0}=$ quantity of ith itel purchased in the refernce period

${ }^{\mathrm{k}} 100 \mathrm{bps}=1 \%$

${ }^{1}$ Taken from inaugural address by Dr. D. Subbarao, Governor, RBI, at the 7th Statistics Day Conference of RBI, Mumbai, on August 30, 2013, on "Statistics in RBI's Policy Making Conceptual and Empirical Issues".

${ }^{m}$ PPI: Producer Price Index. The equivalent of producer prices in India is the WPI.

${ }^{\mathrm{n}}$ Consumer and Producer prices here imply CPI and WPI respectively. However, CSO manual (2017) states that WPI in India is not a good approximation of producer prices.

${ }^{\circ}$ ARIMA: Autoregressive Integrated Moving Average

P The unit-root test results for the sub sample 2008M1 to 2013M12 are not presented for the sake of brevity

${ }^{\mathrm{q}}$ Lag selection criteria: AIC: Akaike Information Criteria; Schwarz Bayesian Criteria; LR: Likelihood Ratio

${ }^{\mathrm{r}}$ Various dummy variables are used in both specifications which capture the strong effect of outliers and/or structural break in the series especially during 1998-99 and global financial crisis. Final estimated model is selected after carefully examining the impact of these different dummy variables. 